\title{
Vegetation characteristics of green facades, green cloaks and naturally colonized walls of wooden barns located in the Mid-Atlantic Region of North America
}

\author{
David Tilley $^{1}$, Serena Matt ${ }^{2}$, Laura Schumann ${ }^{3}$ and Patrick Kangas ${ }^{4}$ \\ 1 Associate Professor, University of Maryland, College Park, MD, dtilley@umd.edu \\ 2 Previous Graduate Student, University of Maryland, College Park, MD \\ 3 Previous Graduate Student, University of Maryland, College Park, MD \\ 4 Associate Professor, University of Maryland, College Park, MD, pkangas@umd.edu
}

Tilley, D., Matt, S., Schumann, L., Kangas, P., 2014. Vegetation characteristics of green facades, green cloaks and naturally colonized walls of wooden barns located in the Mid-Atlantic Region of North America. Journal of Living Architecture. 1(3): 1-35.

http://greenroofs.org/resources/JOLA2014Volume1(Issue3)Tilley(etal) 


\begin{abstract}
We quantified the amount and diversity of vegetation on ten green facades and compared it to nine naturally colonized wooden barns located in the humid temperate climate of eastern North America. The leaf area index (3.3 $\mathrm{m}^{2}$-vegetation $/ \mathrm{m}^{2}$-wall) and canopy thickness $(61 \mathrm{~cm})$ of the green facades was nearly identical to that of the barns $(3.1$ and $69 \mathrm{~cm}$ ), indicating that green facades mimic nature's architecture. Predicting the biomass of façades from models developed for the barns' canopies, indicated they should range from 1000 to $1400 \mathrm{~g} / \mathrm{m}^{2}$ (5600 to $8000 \mathrm{~g} / \mathrm{m}^{2}$, fresh weight) but could be as much as 2900 $\mathrm{g} / \mathrm{m}^{2}\left(21,000 \mathrm{~g} / \mathrm{m}^{2} \mathrm{fw}\right)$. The façades included a total of 14 vine species while the barns included 8. There was an average and maximum of 3.2 and 6 species on the facades and 2.3 and 4 on the barns. The biodiversity of the cultivated system closely mirrors the colonized system, suggesting that an optimum biodiversity may exist for vertical, vinebased living architectures.
\end{abstract}

Keywords: green walls, biomass, leaf area index, vines

\title{
Introduction
}

A green wall is vegetation growing on or near a built vertical structure. Growing vines on building façades or free-standing walls for benefits such as shade, fruit, or ornament is not a modern invention but the practice is becoming more common as the green building industry endorses it (Kohler 2008). A green façade, one modern version of the green wall, is defined as a vertical system for supporting woody or herbaceous climbers and vines, which are typically planted in the ground or in planter boxes. The support system can be free-standing or fastened to the building so that vegetation covers all or a portion 
of the envelope, but is not attached to it (Price, 2010). A green cloak was defined by Schumann and Tilley (2008) as a vine canopy suspended horizontally above a flat or slightly sloping roof, as opposed to the vertical orientation of the green facade. A reason for designing the green cloak was to have an ecologically engineered system that provided some of the same ecosystem services of an intensive or extensive green roof, but less onerous roof load requirements.

Urbanization has resulted in habitat loss, alteration, fragmentation, and isolation (Adams et al. 2005), and is the second most frequently cited cause of species endangerment in the United States (Czech and Krausman 1997). The high population density and high rate of material consumption and waste production associated with urban systems has impaired air, water, and soil quality both within and around cities (Adams et al. 2005), while increased hard-scape and limited vegetative coverage have influenced climate and the water balance (Alfsen-Norodom 2004).

Similar to other living architecture technologies, like green roofs and rain gardens, green walls offer benefits to urban residents, building owners and occupants, the local climate, local ecosystems, and water balance (Francis and Lorimer 2011). Adding vegetation to roofs in urban centers has been shown to mitigate stormwater runoff (Nagase and Dunnett, 2012; Dunnett and Kingsbury 2008), regulate ambient and building temperatures (Dvorak and Volder, 2013; Oberndorfer et al. 2007), potentially reduce road traffic noise by as much as 7 decibels (Van Renterghem et al. 2013) or a few percent (Fernandez-Bregon et al. 2012), and provide wildlife habitat (Coffman and Davis 2005, Baumann 2006, Brenneisen 2006, Kadas 2006, MacIvor and Lundholm 2011). However, Chen (2013) questioned whether these ecological benefits were materializing in Taiwan, 
conjecturing that green roof retention of runoff was much less in hot, wet tropical climates because most of the precipitation fell in liquid form (as opposed to frozen) during the rainy season as opposed to being more evenly distributed temporally in high latitude zones.

In addition to making the green wall "green", vegetation is the primary producer that intercepts and transforms the environmental inputs of solar energy, vapor pressure deficits, wind velocities, water and nutrients into other forms of energy. These other forms of energy, like latent energy for evaporative cooling and photosynthetically produced chemical energy, support an ensuing ecological web of herbivores, consumers, and detritivores. Thus, the qualities and quantity of vegetation on a green wall are key indicators of the auxiliary ecological functions that it can support.

In eastern North America, vine plant communities tend to proliferate in areas along the edges of natural (e.g., forests) and built (e.g., fences) structures where there is readily available sunlight. Vines are an important life-form in terrestrial plant communities. In tropical forests vines literally tie the canopy together, they produce enormous amounts of leaf litter, can account for nearly $25 \%$ of the stems, compete for light, water and nutrients, and provide structural support for canopy-dwelling mammals (Putz and Mooney 1991, Putz et al. 1989). Their elongated stems and attachment mechanisms allow them to use other plants for support as they growth up through the canopy. Because they do not invest energy in support structures, vines have a number of morphological and physiological adaptations for fast growth and competitive advantage, relative to other plant life-forms (Putz 1995). Although the highest diversity of vine species is found in the Tropics (Richards 1952, Janzen 1975), the vine life-form occurs 
world-wide in plant communities. The main attributes of vine species include woody vs. non-woody stems along with the method of climbing and attachment. Ecologically, vines can dominate plant communities after disturbance or on edges where sunlight intensity is high (Hegarty and Caballe 1991, Penfound 1966, Sharp 1974). The ecological engineering challenge of green facade and green cloak systems is to design artificial support structures and management regimes that take advantage of vine adaptations for improving the energetics, water balance, air quality, habitat and visual appeal of the built environment.

Since natural systems can often be the inspiration for living technologies (e.g., ecological engineering: Kangas 2003, biomimicry: Benyus 1997, Chapman et al. 2014), we thought it would be insightful to investigate the plant diversity and standing biomass of naturally colonized built structures that supported a seemingly productive vine community. In addition, since natural vine communities are much more widespread than built green facades, it could prove informative for design and maintenance of green facades to know the growing conditions and requirements for successful local and regional vine communities. Lastly, ecologically inspired innovation needs more examples and case studies to demonstrate to the public and budding eco-inventors that nature's designs can continue to be adapted to support sustainable development.

The aims of this study were to compare the species diversity and amount of vegetation supported by vertically oriented green façades located in an urban environment to that supported by naturally colonized wooden barns located in a rural environment and to that of horizontally oriented green cloaks located in a controlled plant nursery; all of which were subjected to the humid, temperate climate of eastern North America. 


\section{Methods}

\section{Site and System Descriptions}

\section{Green Facades}

Green façades were located in the Washington D.C. Metropolitan Area. All but one of the trellis systems were fabricated rigid-steel constructions manufactured by the same company (Greenscreen, Los Angeles, CA); the single exception included stainless steel cable systems, which were located on small wooden barns at the University of Maryland Clarksville Farm. While each Washington, D.C. façade was installed, planted, maintained and owned by a different organization, the Clarksville Farm green facades were planted and maintained by the authors as part of a multi-year study to investigate vegetative growth, energetic effects and hydrology of green facades (Tilley et al. 2012). All other green facades were located on parking garages, office buildings, or apartment complexes located within metropolitan Washington.

\section{Green Cloaks}

Experimental green cloaks were manufactured at the University of Maryland Ecosystem Engineering Design Lab using potted vines and trellis made from PVC tubing and galvanized 14-gauge wire in a square pattern with 6 inch spacing. Vine plants were started either from seed or cuttings in the UMD Research Greenhouse prior to being potted for the cloaks (Table 1). Each cloak consisted of one species. Once a species of a potted plant became large enough, it was attached to the trellis of the cloak. The cloaks were grown in greenhouse under natural and artificial light, temperature, and relative humidity conditions that emulated a typical eastern North America summer. Cloaks were 
watered three times per week and fertilized (Jack's 20-10-20, Allentown, PA) once per week. We provided water and nutrients to the vines at a greater rate than would be available from natural processes so that they would not be limited by resources. This regimen likely encouraged the maximum growth rates. On May 12, 2006, once the threat of frost was gone, cloaks were moved outside of the greenhouse and maintained in ambient conditions until September of 2006 at which time they were harvested for biomass. Cloaks were watered daily, but only fertilized once while outside (Nutricote 18-6-8, Bellevue, WA). 
Table 1. Schedule and method for starting plants on the green cloak.

\begin{tabular}{|c|c|c|c|c|}
\hline Scientific Name & Cloak Common Name & Date Planted & $\begin{array}{l}\text { Date Added } \\
\text { to Cloak }\end{array}$ & Source \\
\hline $\begin{array}{l}\text { Ampelopsis } \\
\text { brevipedunculata }\end{array}$ & Porcelain berry & 1-Jul-05 & 17-Aug-05 & Clipping from College Park, MD \\
\hline \multirow[t]{2}{*}{$\begin{array}{l}\text { Parthenocissus } \\
\text { quinquefolia }\end{array}$} & Virginia creeper 1 & 1-Jul-05 & 17-Aug-05 & Clipping from College Park, MD \\
\hline & Virginia creeper 2 & 1-Jul-05 & 17-Aug-05 & Clipping from College Park, MD \\
\hline \multirow[t]{2}{*}{ Pueraria lobata } & Kudzu 1 & 15-Jul-05 & 22-Sep-05 & Purchased seed \\
\hline & Kudzu 2 & 15-Jul-05 & 10-Jan-06 & Purchased seed \\
\hline Lonicera japonica & Japanese honeysuckle & 11-Nov-05 & $15-F e b-06$ & Clipping from Silver Spring, MD \\
\hline Campsis radicans & Trumpet vine & 11-Nov-05 & 14-Mar-06 & Clipping from Silver Spring, MD \\
\hline Bignonia capreolata & Cross vine & 11-Nov-05 & 11-May-06 & Clipping from Silver Spring, MD \\
\hline Ipomoea tricolor & Morning glory & 14-Mar-06 & 11-May-06 & Purchased seed \\
\hline Thunbergia alata & Black eyed Susan vine & 14-Mar-06 & 6-Jul-06 & Purchased seed \\
\hline Ipomoea alba & Moonflower & 14-Mar-06 & 6-Jul-06 & Purchased seed \\
\hline
\end{tabular}

\section{Wooden Barns}

Wooden barns, naturally colonized by vines, were located near rural Friendship, MD, which is approximately 25 miles east of Washington, DC, 25 miles south of Annapolis, MD, and immediately west of the Chesapeake Bay. Most of the wooden barns were former tobacco barns that had a variety of current uses. Barns were selected based on access, presence of a vine community and proximity to each other. The local area around Friendship was canvassed for potential sites by driving an automobile along state and county roads. Barns that appeared to be abandoned, wooden tobacco barns were among our first choices because they were plentiful in the region, located close by, and often supported vine communities. Since tobacco farming in this region of southern Maryland 
had been largely abandoned by the early 2000 's, there were a number of barns available. Once a list of potential barns was identified, we approached the presumed owner to ask permission to study the vine community covering their barn. If permission was granted, the barn became part of the study. Occasionally, the owner could not be identified which precluded the barn from our study.

\section{Data Collection}

\section{Green Facades}

The traditional definition of leaf area index (LAI) of an ecological plant community is the amount leaf surface area per ground area in units of $\mathrm{m}^{2}$ of leaf surface per $\mathrm{m}^{2}$ of ground area. Thus, it is often written without units since area cancels out. LAI is an important parameter for describing terrestrial plant communities because it corresponds to the photosynthetic capacity of the ecosystem. For the vertical green wall communities we modified the definition of LAI to be the amount of leaf area per wall area, thus it is defined for the vertical plane, not the horizontal as with its traditional use.

The LAI of the green facades was found by using the point intercept method. At each $0.56 \mathrm{~m}^{2}$ quadrat, a $1-\mathrm{cm}$ diameter $60-\mathrm{cm}$ long rod was inserted across the vertical plane of façade canopy at 6 evenly spaced locations. The average number of times the rod was contacted by vegetation was taken as the LAI.

Maximum vine canopy thickness was measured as the horizontal distance between the outer edge of the steel trellis of the facade and the most extreme member of the vine canopy within each quadrat. Thus, like "vertical" LAI above, thickness was also defined relative to the vertical plane of the façade. Vine Percent Cover of each green façade was 
visually estimated for the entire area covered by the steel trellis. Total Vine Area (i.e., the two dimensional extent of vine growth on the entire building wall) was estimated as Vine Percent Cover multiplied by the area of the steel trellis. The area covered by the steel trellis was estimated from the width, measured with a tape-measure, and from the height, estimated from the number of panels and per unit height of individual panels.

Vine species richness (Vine Richness) was found by counting the total number of vine species on each green façade installation. Vines that were not already identified with labels were identified using available planting plans or comparison of samples to the USDA PLANTS database (USDA, NRCS. 2013).

The growth of the vine communities were sampled in June, July and August in 2011. Biomass was not collected from the green facades due mainly to owners' concerns for aesthetic degradation.

\section{Wooden Barns}

Leaf area index, canopy thickness and biomass samples were taken from three $0.25 \mathrm{~m}^{2}$ quadrats at each wooden barn during a single visit between July 14 and August 25, 2006. For each of the quadrats, five subsample measurements of LAI were made using the point intercept method and averaged to estimate the LAI of each quadrat. Canopy thickness was defined as the perpendicular distance from the surface of the building to the most outer edge of vine canopy. Three subsample measurements of canopy thickness were made at each quadrat and averaged to estimate thickness at each quadrat.

The biomass from each of the three quadrats at each barn was harvested using hand tools (e.g. pruning scissors) and bagged in paper sacks. Biomass was sorted as either "woody" 
or "non-woody" for later analysis. Woody biomass was defined as vegetation with stem diameters greater than $0.6 \mathrm{~cm}$ while non-woody biomass was all vegetation with stems less than $0.6 \mathrm{~cm}$. We chose this diameter because prior observations had indicated that first-year growth of vine stems rarely exceeded $0.5 \mathrm{~cm}$. Subsamples of the woody and nonwoody samples were oven dried and then the ratio of green to dry weight of the subsamples was used to determine the total dry weight of the quadrat samples.

The azimuth of the sampled wall was determined using a handheld compass. The aboveground height of quadrats was measured using a handheld meter stick. Species were identified and the number of vine species growing on the entire sampled wall was counted. All barns were revisited on September 29, 2006 to measure photosynthetically active radiation (PAR, i.e, visible sunlight) above and below the canopy using the same methods described below for the green cloaks.

\section{Green Cloaks}

LAI of each cloak was measured weekly with the point-intercept method as described above for the green facades and wooden barns. Six subsample measurements were averaged to represent the LAI of a cloak.

Canopy thickness for each cloak was found by averaging three measurements of the distance between the cloak trellis and the top of the vine canopy. Maximum thickness was measured similarly except it was the distance between the cloak trellis and the highest leaf. Percent cover was estimated visually as the percentage of the cloak trellis that was covered with vines. 
At the end of the growing season in September 2006, we measured the PAR above and below the canopy, number of species per cloak, and total biomass. We measured downwelling and transmitted PAR on the half of the cloak with the densest canopy using a quantum solar cell (Apogee Instruments, Inc. Quantum Meter Model QMSW-SS, Roseville, CA) on September 22, 2006 at 3:00 pm. The measured half was oriented at 146 degrees from north because this was the mean orientation of naturally colonized wooden barns described above. However, the orientations of the barns varied from dueeast to due-west with some facing south and none facing north. The standard deviation of the orientation was $65^{\circ}$. The PAR meter was oriented perpendicular to the canopy surface for each measurement, which consisted of one above canopy sample, five below canopy samples arranged in an " $\mathrm{X}$ " formation, and then one more above canopy sample. PAR subsamples were averaged to estimate above and below canopy measurements. The percentage transmittance of PAR through the cloak canopy was found by dividing the below canopy measurement by the above canopy measurement.

Total biomass of each cloak was harvested from a $0.25 \mathrm{~m}^{2}$ quadrat. Subsamples were oven dried to determine the ratio of the green to wet weight of the subsamples and then used to estimate the total dry weight of the cloaks.

Species were identified and the number of vine species on each cloak was counted in September 2006.

\section{Data Analysis}

Correlations among the vegetation characteristics of the green facades was conducted using SAS 9.0 (SAS Institute, Cary, NC) with alpha levels of 0.05 and 0.10. Time series plots of canopy thickness, LAI and cover of the green facades during the summer were 
constructed to detect short-term dynamics. To compare canopy thickness, LAI and species richness among the wooden barns, green cloaks and green facades we calculated minima, maxima and means of each attribute. We did the same for biomass, which did not include the green facades. Simple linear regression was used to detect the rate of increase of thickness, biomass, LAI and cover of the green cloaks during their first year of growth. Similarly, regression was used to detect relationships among biomass, LAI and thickness of the green cloaks and wooden barns.

\section{Results}

\section{Green facades}

The percent cover, thickness and LAI of vines on the green facades peaked in June and July but stayed relatively stable during the summer (Figure 1). Over the course of the summer, mean Vine LAI dropped nearly $1 \mathrm{~m}^{2} / \mathrm{m}^{2}$ from $3.75 \mathrm{~m}^{2} / \mathrm{m}^{2}$ (Figure 1), but remained unchanged at 6 of 10 sites. Mean Vine Thickness was the unchanged from June to July, and but decreased by $10 \%$ by August (Figure 1) and remained unchanged at $80 \%$ of the sites. Mean Vine Percent Cover was basically stable at 35 to $40 \%$ for the entire summer (Figure 1), and remained unchanged at $40 \%$ of the sites, increased at $30 \%$ and decreased at $30 \%$. 
Figure 1. Cover, thickness and leaf area index (LAI) of the green facades during summer. Error bars are standard errors $(n=10)$.

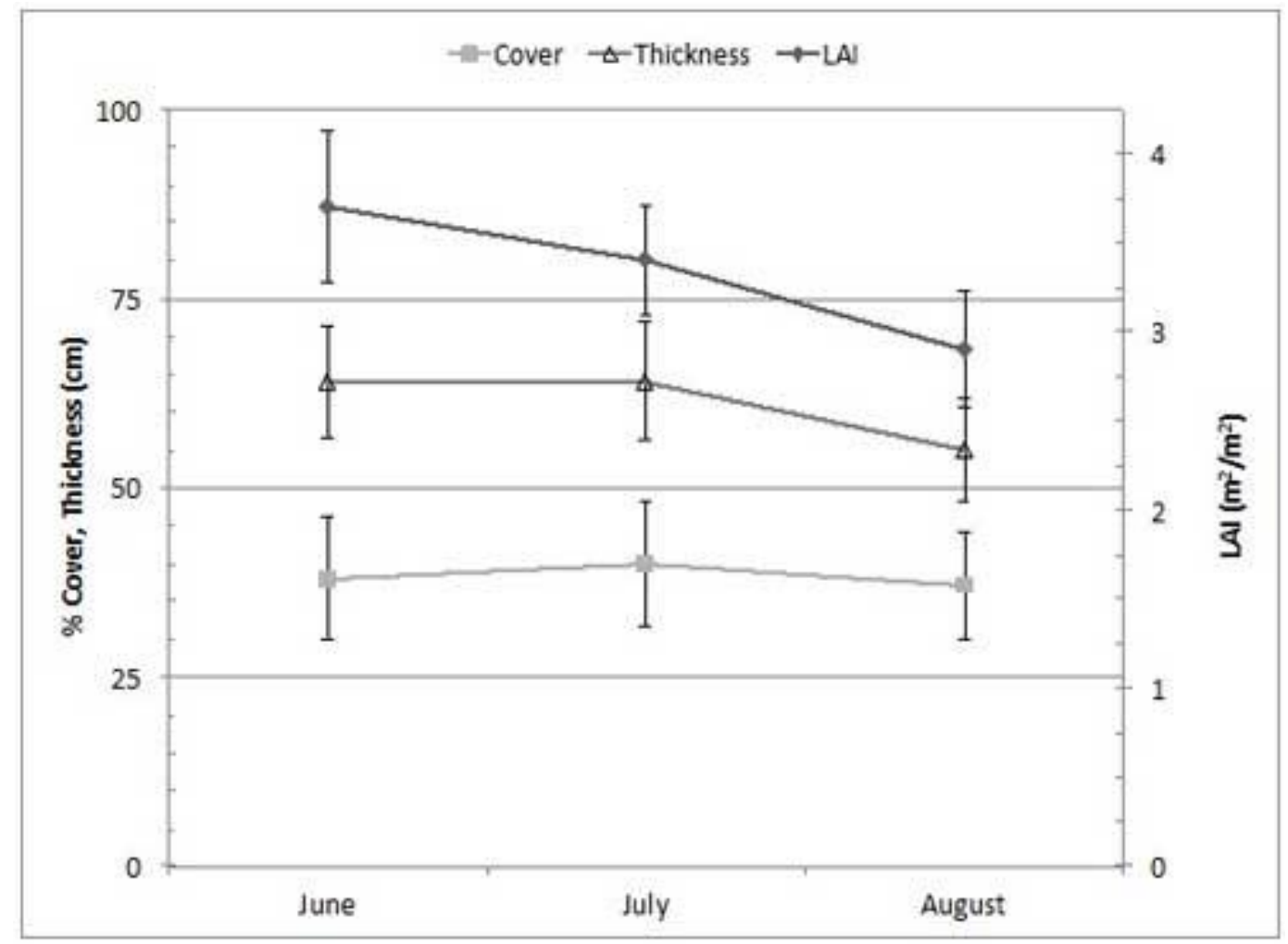

There was a wide range of biomass on the green facades as evidenced by the minima and maxima of LAI, percent cover and thickness (Table 2). In June and August, vines with thicker canopies had higher LAI's (Table 3). 
Table 2. Pooled mean, standard error (SE) minimum and maximum measures of Vine LAI, Vine Percent Cover, and Vine Thickness for all ten green façade sites in June, July and August, 2011.

$$
\text { Vine LAI }\left(\mathrm{m}^{2} / \mathrm{m}^{2}\right) \quad \text { Vine Percent Cover Vine Thickness }(\mathrm{cm})
$$

\begin{tabular}{|c|c|c|c|c|c|c|c|c|c|c|c|c|}
\hline & Mean & S.E. & Min & $\operatorname{Max}$ & Mean & S.E. & Min & Max & Mean & S.E. & Min & Max \\
\hline June & 3.7 & 0.42 & 1.5 & 5.9 & 38 & 8.01 & 1.5 & 70.4 & 64 & 7.33 & 29.2 & 105.9 \\
\hline July & 3.4 & 0.31 & 1.6 & 4.9 & 40 & 8.23 & 3.5 & 84.5 & 64 & 7.71 & 30.7 & 98.2 \\
\hline August & 2.9 & 0.33 & 1.5 & 5.4 & 37 & 7.02 & 3.2 & 64.5 & 55 & 6.77 & 30.6 & 82.8 \\
\hline
\end{tabular}

Table 3. Correlation among vegetation properties of the green facades. ${ }^{*} \mathrm{p}<0.05, * * \mathrm{p}<0.01$.

\begin{tabular}{lcccc}
\hline Characteristic & $\begin{array}{c}\text { Vine } \\
\text { LAI }\end{array}$ & $\begin{array}{c}\text { Vine } \\
\text { Richness }\end{array}$ & $\begin{array}{c}\text { Vine } \\
\text { Thickness }\end{array}$ & Vine Age \\
\hline JUNE & & & & \\
$\quad$ Vine LAI & 1.0 & -0.18 & $0.72^{* *}$ & -0.03 \\
Vine Richness & & 1.0 & -0.02 & -0.31 \\
Vine Thickness & & & 1.0 & 0.46 \\
$\quad$ Vine Age & & & & 1.0 \\
JULY & 1.0 & -0.09 & 0.50 & 0.12 \\
$\quad$ Vine LAI & & 1.0 & 0.15 & -0.31 \\
Vine Richness & & & 1.0 & 0.53 \\
Vine Thickness & & & & 1.0 \\
$\quad$ Vine Age & & & & \\
AUGUST & 1.0 & -0.15 & $0.55^{*}$ & 0.09 \\
$\quad$ Vine LAI & & 1.0 & 0.08 & -0.31 \\
Vine Richness & & & 1.0 & $0.61^{*}$ \\
Vine Thickness & & & & 1.0 \\
Vine Age & & &
\end{tabular}

The age of the vines planted on the ten green façades ranged from newly planted to 17 years old with a mean of 5.2 years (Table 4). Older green facades tended to cover more area for all 3 months (Table 3). Vine Index was developed to capture the structural complexity of the green façades and consisted of LAI, thickness, and species richness. 
Age and area were not related to the structural index (Table 3). The index was only related to its components. 
Table 4. Minimum, average (standard deviation) and maximum growth characteristic comparisons of vines growing on barns, green cloaks and green facades.

\section{Wooden Barns \\ Green Cloak \\ Green Facade}

\begin{tabular}{|c|c|c|c|c|c|c|c|c|c|}
\hline Measurement & Minimum & Average & Maximum & Minimum & Average & Maximum & Minimum & Average & Maximum \\
\hline \multicolumn{10}{|l|}{ Biomass $\left(\mathrm{g} / \mathrm{m}^{2}\right)$} \\
\hline Total & 345.2 & $\begin{array}{l}1250.9 \\
(945.6)\end{array}$ & 3647.6 & 96.8 & $\begin{array}{c}546.6 \\
(464.1)\end{array}$ & 1685.6 & n.a. & n.a. & n.a. \\
\hline Woody* & 47.2 & $\begin{array}{c}513.6 \\
(511.5)\end{array}$ & 1727.2 & 0 & $\begin{array}{c}0 \\
(0)\end{array}$ & 0 & n.a. & n.a. & n.a. \\
\hline Nonwoody & 269.6 & $\begin{array}{c}769.1 \\
(473.8)\end{array}$ & 1920.4 & 96.8 & $\begin{array}{c}546.6 \\
(464.1)\end{array}$ & 1685.6 & n.a. & n.a. & n.a. \\
\hline $\begin{array}{l}\text { Canopy Thickness } \\
(\mathrm{cm})^{*}\end{array}$ & 38 & $\begin{array}{c}69.7 \\
(31.3)\end{array}$ & 131.7 & 12.3 & $\begin{array}{c}21.7 \\
(6.68)\end{array}$ & 31.5 & 30.2 & $\begin{array}{l}61.0 \\
(22.6)\end{array}$ & 95.6 \\
\hline Leaf Area Index* & 1.47 & $\begin{array}{l}3.14 \\
(1.1)\end{array}$ & 5 & 0.67 & $\begin{array}{l}1.73 \\
(1.0)\end{array}$ & 3.67 & 1.5 & $\begin{array}{c}3.3 \\
(1.1)\end{array}$ & 5.4 \\
\hline Percent Cover & n.a. & n.a. & n.a. & 50 & $\begin{array}{l}76 \\
(21)\end{array}$ & 100 & 3.5 & $\begin{array}{l}40 \\
(24)\end{array}$ & 84.5 \\
\hline Light Transmission, \% & 4.5 & $\begin{array}{l}17.3 \\
(11.0)\end{array}$ & 37.0 & 3.4 & $\begin{array}{l}26.8 \\
(20.1)\end{array}$ & 72.5 & n.a. & n.a. & n.a. \\
\hline Vine Richness* & 1 & 2.33 & 4 & 1 & 1 & 1 & 1 & 3.2 & 6 \\
\hline Age (y) & n.a. & n.a. & n.a. & 1 & 1 & 1 & 0.1 & $\begin{array}{c}5.2 \\
(5.0)\end{array}$ & 17 \\
\hline
\end{tabular}


One to six vine species were planted on any individual green façade representing a total of 12 different species with only 2 non-natives present (Table 5). The mean number of vine species on a green façade was 3.2 (Table 4).

Older green façades tended to have more panel area (Figure 2). The four smallest set of panels were on facades that were less than three years old. In general older facades supported a higher percent cover than younger ones (Figure 2). The one year old façade at our Clarksville facility, which was irrigated daily and fertilized weekly, appeared to be an outlier so we removed it to find that indeed percent cover was strongly $\left(R^{2}=0.64\right)$ related to the age of the green facades (Figure 2). Interestingly, the maximum percent cover was about $70 \%$ when all 10 sites were considered. Thicker vine canopies were also found on older green façades where the maximum was slightly above $80 \mathrm{~cm}$ (Figure 2). 


\begin{tabular}{|c|c|c|c|c|}
\hline Scientific name & Common name & Cloaks & Barns & Facades \\
\hline \multicolumn{5}{|c|}{ Common Among 3 Systems } \\
\hline Parthenocissus quinquefolia & Virginia creeper & $\mathrm{X}$ & $\mathrm{X}$ & $\mathrm{X}$ \\
\hline \multicolumn{5}{|c|}{ Common Between at least 2 Systems } \\
\hline *Lonicera japonica & Japanese honeysuckle & $\mathrm{X}$ & $\mathrm{X}$ & \\
\hline Campsis radicans & Trumpet creeper & & $\mathrm{X}$ & $\mathrm{X}$ \\
\hline Vitis sp. & Grape & & $\mathrm{X}$ & $\mathrm{X}$ \\
\hline Bignonia capreolata & Cross vine & $\mathrm{X}$ & & $\mathrm{X}$ \\
\hline \multicolumn{5}{|c|}{ Unique to 1 System } \\
\hline Ipomoea alba & Moonflower & $\mathrm{X}$ & & \\
\hline *Ampelopsis brevipedunculata & Porcelain berry & $\mathrm{X}$ & & \\
\hline *Campsis grandiflora & Chinese trumpet vine & $\mathrm{X}$ & & \\
\hline *Ipomoea tricolor & Morning glory & $\mathrm{X}$ & & \\
\hline *Pueraria lobata & Kudzu & $\mathrm{X}$ & & \\
\hline *Thunbergia alata & Black-eyed susan vine & $\mathrm{X}$ & & \\
\hline Hydrangea arborescens & Wild hydrangea & & $\mathrm{X}$ & \\
\hline Rubus argutus & Blackberry & & $\mathrm{X}$ & \\
\hline Smilax rotundifolia & Greenbrier & & $\mathrm{X}$ & \\
\hline Toxicus radicans & Poison ivy & & $\mathrm{X}$ & \\
\hline *Akebia quinata & Chocolate vine & & & $\mathrm{X}$ \\
\hline Celastrus scandens & American bittersweet & & & $\mathrm{X}$ \\
\hline *Clematis terniflora & Sweet autumn virginsbower & & & $\mathrm{X}$ \\
\hline Gelsemium sempervirens & Carolina jessamine & & & $\mathrm{X}$ \\
\hline Lonicera sempevirens & Coral honeysuckle & & & $\mathrm{X}$ \\
\hline *Parthenocissus tricuspidata & Boston Ivy, Japanese creeper & & & $\mathrm{X}$ \\
\hline Trachelospermum jasminoides & Confederate jasmine & & & $\mathrm{X}$ \\
\hline Wisteria frutescens & American wisteria & & & $\mathrm{X}$ \\
\hline
\end{tabular}


Figure 2. Relationships between total panel area, percent cover (all 10 sites), percent cover with irrigated Clarksville site removed, canopy thickness and age of the green façade installation
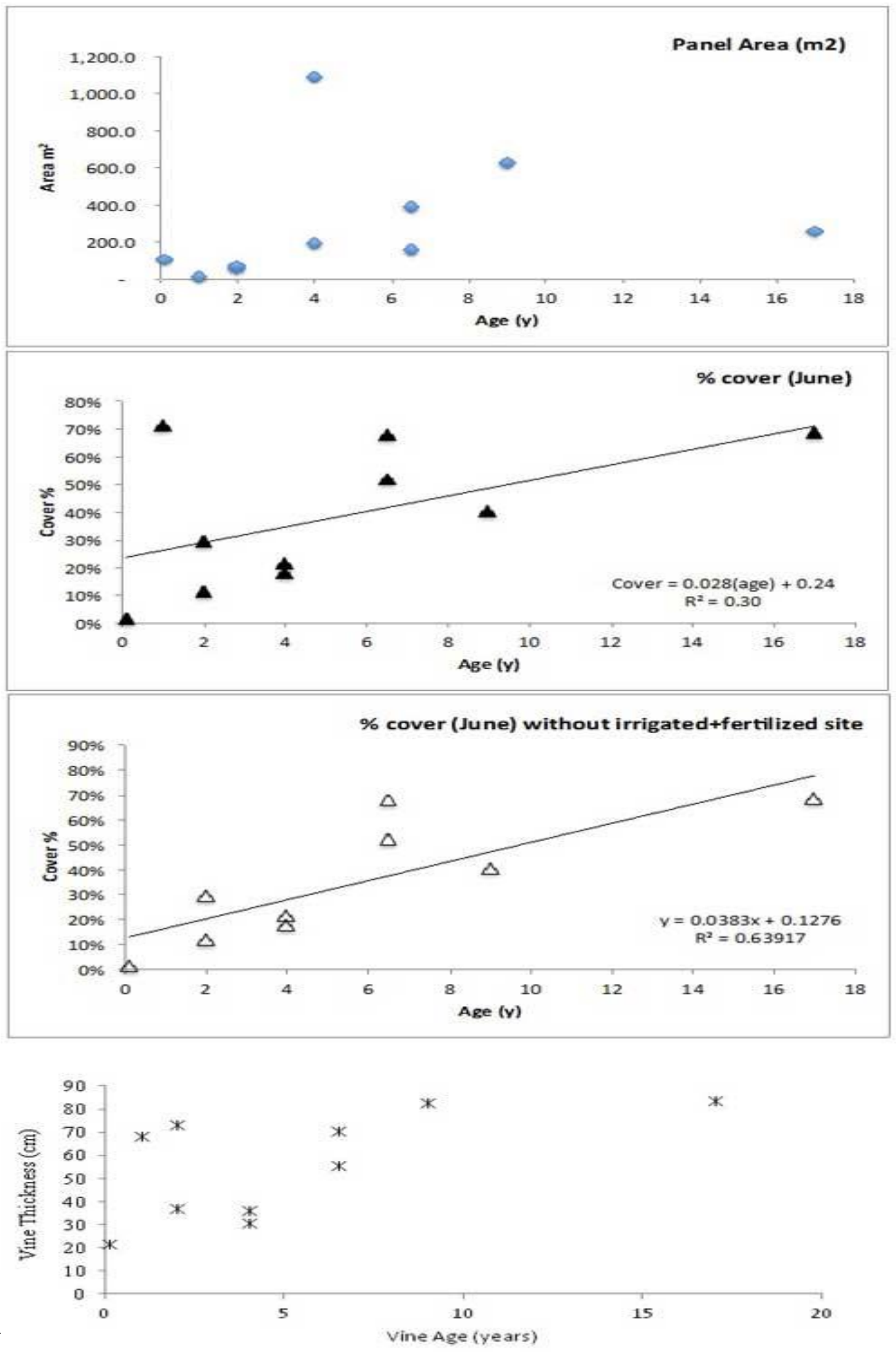


\section{Green cloaks}

The canopy thickness, aboveground biomass, LAI and percent cover of the 11 green cloaks all increased significantly during their first year of growth (Figure 3). Species did not seem to make much difference in growth response. With only one year of growth it is difficult to know whether any of the vegetation characteristics had reached a maximum, however thickness did seem to reach its maximum of $25 \mathrm{~cm}$ by Day 220, while percent cover on $1 \mathrm{~m} 2$ had reached 100\% by Day 200. On the other hand LAI and biomass appeared to be continuing their increase by the end of their first year of growth (Figure

3).

Figure 3. Vegetation characteristics of the canopy of the 11 green cloaks during the first year of growth.

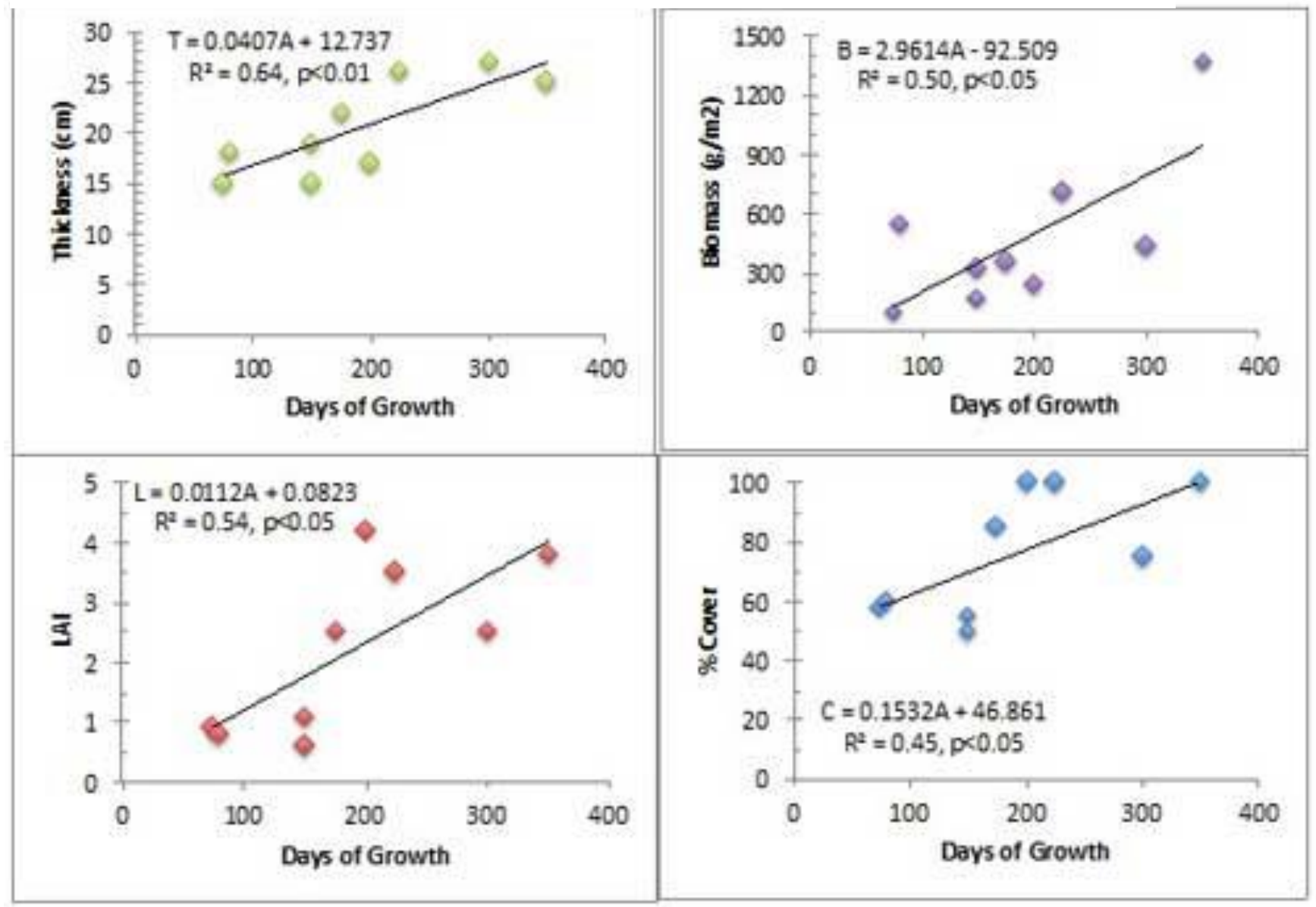


The mean LAI for all 11 cloaks was 1.73, but ranged from 0.67 to 3.67 (Table 4). Thickness of the cloak canopies averaged nearly $22 \mathrm{~cm}$, but ranged from 12.3 to $31.5 \mathrm{~cm}$ (Table 4). Non-woody (and total) biomass on the cloaks averaged $547 \mathrm{~g} / \mathrm{m}^{2}$, but ranged over an order of magnitude from 96.8 to $1686 \mathrm{~g} / \mathrm{m}^{2}$ (Table 4). There was no woody biomass on the cloaks.

LAI of the green cloaks was a strong indicator of the non-woody biomass present in the vine canopies (Figure 4). Each 1 unit increase in LAI corresponded to an extra $276 \mathrm{~g} / \mathrm{m}^{2}$ of non-woody biomass. LAI was also strongly related to canopy thickness on the green cloaks (Figure 5). In general LAI is a useful indicator of the quantity (i.e., biomass) and structure (i.e., thickness) of the vine community of green facades because it is strongly predictive of the two attributes, it is non-destructive and it is easy to measure. 
Figure 4. Relationship of LAI to total biomass of the vine canopies on the (a) naturally colonized wooden barns and (b) green cloaks, and to (c) nonwoody biomass on the naturally colonized wooden barns.

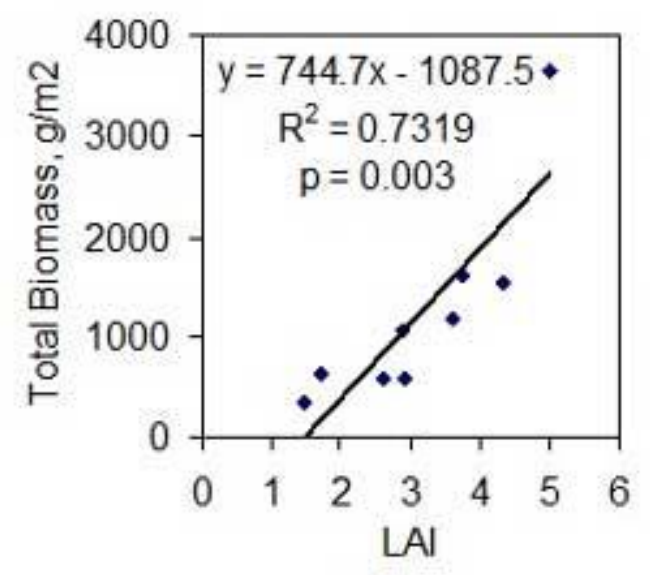

(a)

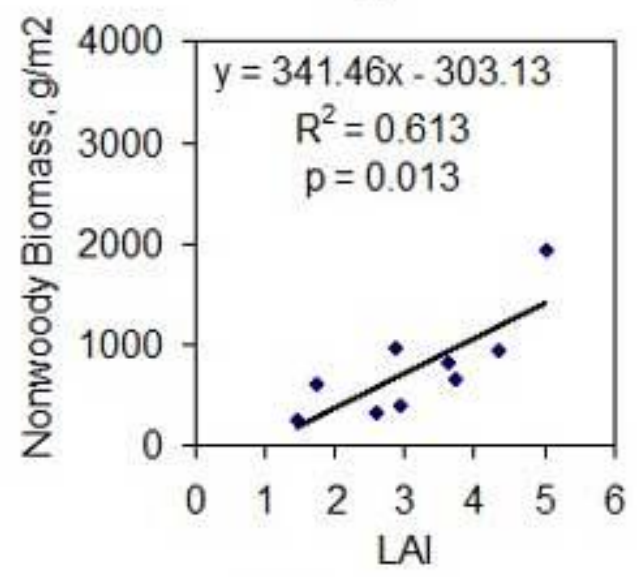

(c)

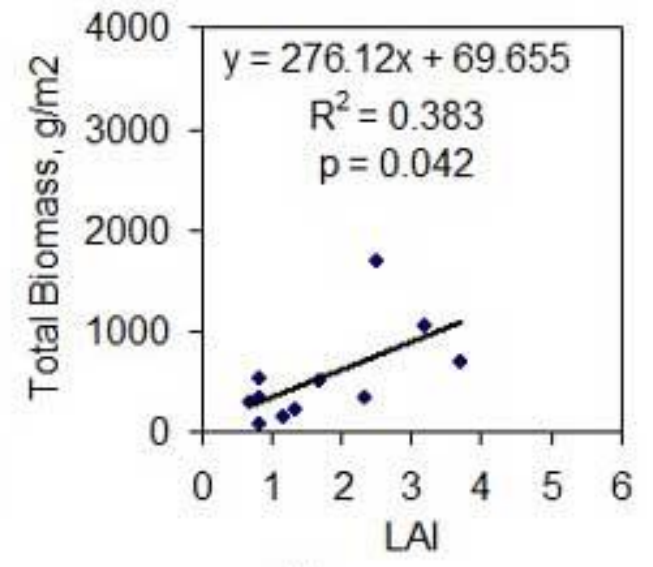

(b) 
Figure 5. Canopy thickness of the wooden barns (left) and green cloak (right) as a function of LAI.
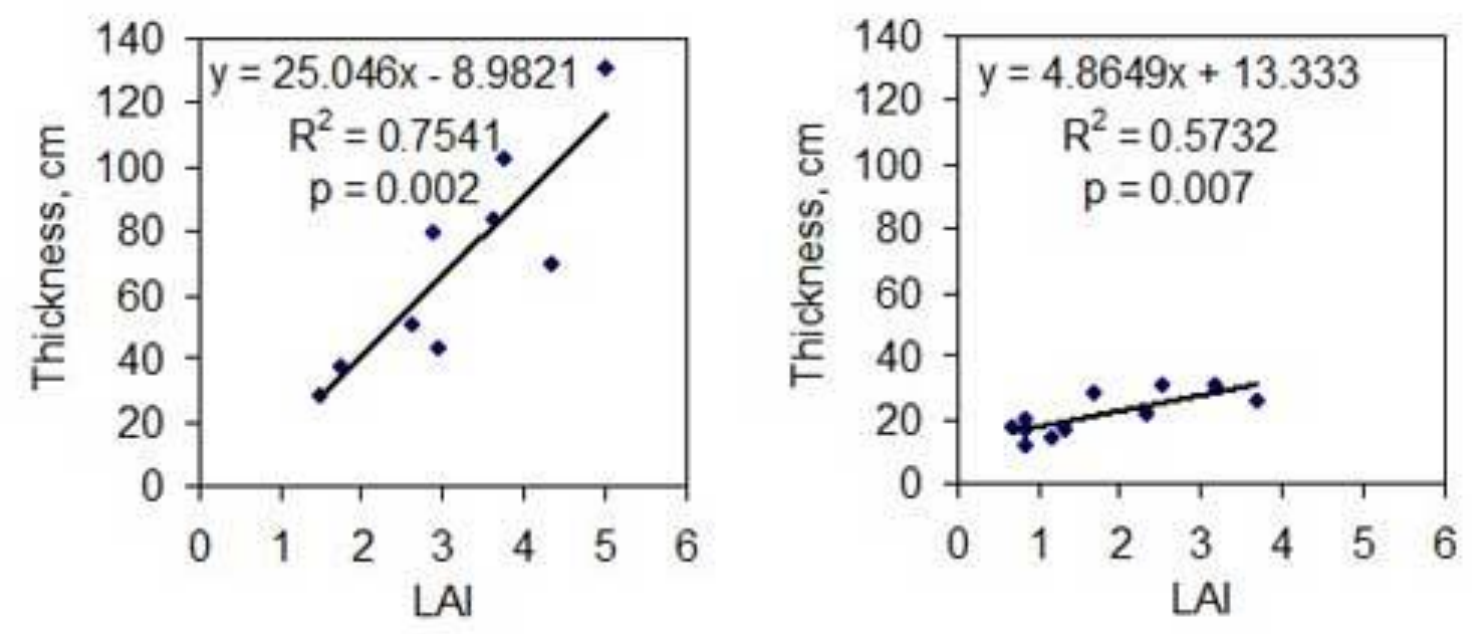

Thickness of the canopy was a moderate indicator $\left(r^{2}=67 \%\right)$ of the amount of above ground biomass for the green cloaks (Figure 6). Each centimeter of canopy corresponded to $57 \mathrm{~g} / \mathrm{m}^{2}$ of biomass. The thickest canopy $(32 \mathrm{~cm})$ had nearly $1700 \mathrm{~g} / \mathrm{m}^{2}$ of biomass.

Each cloak had only one vine species by design and each was one year old (Table 4).

\section{Wooden Barns}

LAI on the nine wooden barns varied widely from 1.5 to 5.0 with a mean of 3.14 (Table

4). Thickness of the vine canopies averaged nearly $70 \mathrm{~cm}$ but was as much as $132 \mathrm{~cm}$ and as little as $38 \mathrm{~cm}$ (Table 4). On average there was more biomass present as non-woody material $\left(769 \mathrm{~g} / \mathrm{m}^{2}\right)$ than as woody material $\left(514 \mathrm{~g} / \mathrm{m}^{2}\right)$ (Table 4$)$. The most dense canopy had more than $3600 \mathrm{~g} / \mathrm{m}^{2}$ of total aboveground biomass as dry weight.

LAI of the wooden barns was a strong indicator of the total and non-woody biomass present in the vine canopies (Figure 4a and 4c). Each 1 unit increase in LAI corresponded to an extra $745 \mathrm{~g} / \mathrm{m}^{2}$ of total biomass and an extra $342 \mathrm{~g} / \mathrm{m}^{2}$ of non-woody biomass. 
LAI was also strongly $\left(r^{2}=75 \%\right)$ related to canopy thickness on the wooden barns with each unit of LAI corresponding to $25 \mathrm{~cm}$ of canopy thickness (Figure 5a). The maximum LAI of 5 corresponded to the maximum thickness of $122 \mathrm{~cm}$.

Thickness of the canopy was a strong indicator $\left(\mathrm{r}^{2}=82 \%\right)$ of the amount of above ground biomass for the wooden barns (Figure 6). Each centimeter of canopy corresponded to 27 $\mathrm{g} / \mathrm{m}^{2}$ of biomass. The thickest canopy $(132 \mathrm{~cm})$ had $3600 \mathrm{~g} / \mathrm{m} 2$ of biomass. 
Figure 6. Relationship between total aboveground biomass and canopy thickness for the green cloaks $(\mathrm{Bg})$ and naturally colonized wooden barns $(\mathrm{Bw})$.

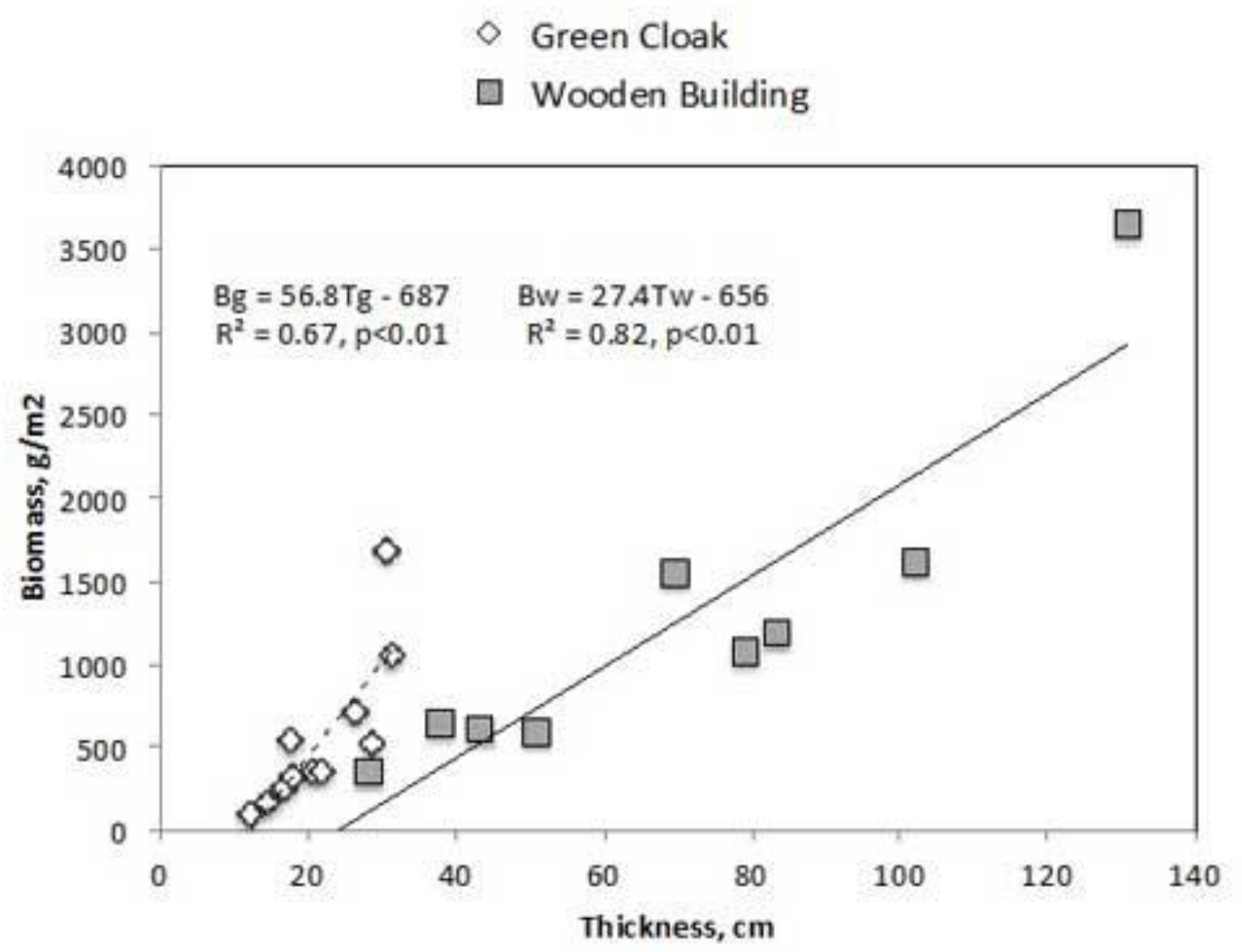

\section{Discussion}

\section{Comparisons}

The LAI of the green facades was nearly identical to the vine community that had naturally colonized the wooden barns (Table 4), indicating that the green facades had fully developed to a level similar to that found in nature. The variability of LAI was also similar between the green facades and the wooden barns, indicating that the amount of leaf material covering vertical surfaces ranges widely under natural and semi-cultivated conditions. The LAI of the green cloaks, which were all a year old or less, had a mean LAI that was about half that of the green facades and wooden barns (Table 4). This 
indicated that the group of vine species on the green cloaks generally needed more than a year to reach their maximum LAI, but several species (e.g., porcelain berry and Virginia creeper) did exceed the mean LAI (3.7) of the green facades and wooden barns in one year, indicating that vine species have various growth rates. Some grow faster than others.

The canopy thickness of the green facades was nearly identical to the vine communities of the wooden barns (Table 4), indicating that the green facades had fully extended their canopies in the horizontal plane like the natural systems. However, unlike LAI, the variability in thickness was not similar between the green facades and the wooden barns (Table 4). While the two systems had similar minima for thickness (30 and $38 \mathrm{~cm}$ ), there was one wooden building with a canopy that extended $132 \mathrm{~cm}$, whereas the thickest green façade was only $96 \mathrm{~cm}$. It is not clear why the natural system was thicker, but it is possibly related to natural variability, species differences, differences in individuals, soil quality or to more woody species inhabiting the wooden barns. In particular, poison ivy (Toxicus radicans), which is a woody species with the ability to extend horizontally beyond a meter (anecdotal observation), was prominent at some of the wooden barns.

\section{Biomass Estimates for Green Facades}

We did not measure biomass on the green facades because most building owners did not approve of it. However, since thickness and LAI were similar between the green facades and wooden barns, and they were both strongly related to biomass, we can estimate the biomass on the green facades based on regression equations developed for the wooden barns (Figures 5a and 8). At the mean LAI of 3.3 for the green facades, we would expect to find $1400 \mathrm{~g} / \mathrm{m}^{2}$ of biomass (dry wt). At the mean thickness of $61 \mathrm{~cm}$ for the green 
facades, we would expect to find $1000 \mathrm{~g} / \mathrm{m}^{2}$ of biomass (dry wt). However, at the maximum thickness of $96 \mathrm{~cm}$ and maximum LAI of 5.4, the estimated biomass of the green facades would range from 2000 to $2900 \mathrm{~g} / \mathrm{m}^{2}$, respectively. The maximum total

biomass observed on the natural systems was nearly $3700 \mathrm{~g} / \mathrm{m}^{2}$. Thus, there appears to be a fairly narrow range in the expected biomass for a green façade $\left(1000-1400 \mathrm{~g} / \mathrm{m}^{2}\right)$, but a wider range in the maximum $\left(2000-3700 \mathrm{~g} / \mathrm{m}^{2}\right)$. The moisture content of the vines on the wooden barns averaged $82 \%$, which means that the expected fresh weight of a green façade ranges from 5600 to $8000 \mathrm{~g} / \mathrm{m}^{2}$ and the maximum could be as high as 21,000 $\mathrm{g} / \mathrm{m}^{2}$

\section{Species}

The 10 green façades had a total of 12 vine species while the 9 natural wooden barns had 8 and the 11 green cloaks had 9. There was an average of 3.2 species on the green facades, 2.3 on the wooden barns and 1 on the green cloaks. There was at most 6 species on a green façade, 4 on a wooden building and 1 on a cloak. The least number of species found on any system was one.

Virginia creeper was the only species common among all 3 systems, whereas Japanese honeysuckle, trumpet creeper, grape and cross vine were found on at least two types of systems (Table 5). The majority of species were unique to a system type (Table 5). In total there were 23 species represented in our study with 8 of them non-native to North America (Table 5). A search of the US Department of Agriculture PLANTS database (USDA, NRCS 2013) revealed that there are 688 species of vines native to the lower 48 States of the U.S. that represent 137 genera, which suggest that our 3 combine systems 
represent only $2 \%$ of the potential species. This suggests that there are many more species to evaluate for their ability to grow on green facades.

The presence of a species on a green façade was a haphazard combination of intentional planting and natural colonization, whereas we must assume (because we do not know their history) that the presence on a wooden building was completely through natural means and we know with certainty that species selected for the green cloaks was intentional. Three vine-based living architectural systems do not provide enough information to generalize about biodiversity, but they do provide some preliminary data that can be used for subsequent comparisons. It is interesting to see that the biodiversity of the cultivated system closely mirrors that of the colonized system, which may suggest that some optimum biodiversity may exist for vertical, vine-based living architectures. Remarkably, the naturally colonized wooden barns had much thicker canopies than the green cloaks for similar LAI values. Each unit of LAI corresponded to $25 \mathrm{~cm}$ of canopy thickness for the naturally colonized barns, but less than $5 \mathrm{~cm}$ for the green cloaks.

\section{Conclusions and Recommendations}

In summary green facades and naturally colonized wooden barns in the humid temperate zone of eastern North America shared similarities in vegetation attributes. Namely, the amount of leaf material, as measured by LAI, the thickness of the canopy, and the number of vine species, were similar between the two types of living architecture. This indicates that the vegetation of green facades is mimicking nature and that the study of natural vine communities can give valuable information about the ecology of green facades. 
The vines' rapid ability to cover the green cloaks within one year suggests that wellmaintained green facades could cover a wall quickly. Likewise, the well-maintained green façade at the Clarksville Farm achieved $70 \%$ vegetation coverage within its first 2 years. In contrast, the unfertilized, non-irrigated and poorly maintained green facades in the Washington metro area added vegetation coverage at a diminished rate of about $4 \%$ per year (Figure 2c), suggesting that a philosophy of no maintenance led to much reduced vine growth. In short, most green facades will need fertilization, irrigation and maintenance to achieve their full vegetative growth potential. Since irrigation and fertilization of vine communities greatly accelerated their growth beyond the low maintenance facades, a future study should employ a more structured experimental design that explicitly considers how vegetation management affects growth.

In addition to questions about vegetation, there is also a need to understand how insects and spiders, birds, reptiles and small mammals, use green facades and how much green facades supplement ecological habitat in urban areas.

\section{Literature Cited}

Adams et al. Adams, L. W., L. W. VanDruff, and M. Luniak. 2005. "Managing urban habitats and wildlife." Pages 714-739 in C. E. Braun, ed. Techniques for wildlife investigations and management, 6th ed. The Wildlife Society. Bethesda, Md. 
Alfsen-Norodom, C., 2004. "Urban biosphere and society: partnerships of cities:

Introduction. In: Urban Biosphere and Society: Partnership of Cities”. AlfsenNorodom, C., B.D. Lane, M. Corry (eds.). Annals of the New York Academy of Sciences 1023: 1-10.

Baumann 2006Baumann, N. 2006. “Ground-nesting birds on green roofs in Switzerland: preliminary observations." Urban Habitats 4:37-50.

Benyus J.M. 1997. “Biomimicry: innovation inspired by nature.” William Morrow \& Co., New York. 308 pp.

Brenneisen 200Brenneisen, S. 2006. "Space for urban wildlife: designing green roofs as habitats in Switzerland." Urban Habitats 4:27-36.

Chapman, J., C. Hellio, T. Sullivan, R. Brown, S. Russell, E. Kiterringham, L. Le Nor, R. Regan, 2014. "Bioinspired synthetic macroalgae: Examples from nature for antifouling applications.” Intl Biodeterioration \& Biodegradation 86: 6-13.

Chen, C.F., 2013. "Performance evaluation and development strategies for green roofs in Taiwan: A review." Ecological Engineering 52: 51-58

DOI:10.1016/j.ecoleng.2012.12.083

Coffman, R.R. and G. Davis. 2005. "Insect and avian fauna presence on the Ford assembly plant ecoroof." In: Proc. of 3rd North American Green Roof Conference: Greening rooftops for sustainable communities, Washington, DC. The Cardinal Group, Toronto. 
Czech, B. and P. R. Krausman. 1997. "Distribution and causation of species endangerment in the United States." Science 277:1116-1117.

Dunnett, N., N. Kingsbury. 2008. "Planting green roofs and living walls.” Timber Press. Portland, OR.

Fernandez-Bregon, N., Urrestarazu, M., Valera, D.L., 2012. "Effects of a vertical greenery system on selected thermal and sound mitigation parameters for indoor building walls." Journal of food, agriculture \& environment 10(3-4): 1025-1027

Francis, R.A., J. Lorimer, 2011. "Urban reconciliation ecology: The potential of living roofs and walls." J. Env. Mngmt. 92: 1429-1437

Hegarty, E. E. and G. Caballe. 1991. "Distribution and abundance of vines in forest communities." Pp. 313-336. in: F. E. Putz and H. A. Mooney (eds.). The Biology of Vines. Cambridge University Press, Cambridge, UK.

Janzen, D. H. 1975. "Ecology of Plants in the Tropics.” Edward Arnold Ltd., London, UK.

Kadas, G. 2006. "Rare invertebrates colonizing green roofs in London.” Urban Habitats $4: 66-86$

Kangas, P.C., 2003. "Ecological engineering: principles and practice." CRC Lewis Publishers, Boca Raton, Florida. 452 pp.

Köhler, M. 1998. "Die Besiedlung von Kletterpflanzen durch Insekten und spinnen” in Berlin. Z. fur Angewandte Zoologie 75(2):195-202 
MacIvor, J.S., Lundholm, J., 2011.”Insect species composition and diversity on intensive green roofs and adjacent level-ground habitats." Urban Ecosystems 14(2): 225-241

Matt, S., D.R. Tilley, P. Shrewsbury, (in review for this issue of JOLA). "Arthropod habitat of green facades in the humid, sub-tropical climate of eastern North America."

Nagase, A., N.Dunnett, 2012. "Amount of water runoff from different vegetation types on estensive green roofs: Effects of plant species, diversity and plant structure." Landscape and Urban Planning 104: 356-363

doi:10.1016/j.landurbplan.2011.11.001

Oberndorfer, E., Lundholm, J; Bass, B., Coffman, RR., Doshi, H., Dunnett, N., Gaffin, S., Kohler, M., Liu, KKY., Rowe, B., 2007. “Green roofs as urban ecosystems: Ecological structures, functions and services." Bioscience 57(10): 823-833

Penfound, W. T. 1966. "The role of vines in plant communities.” L. Chandra (ed.). Advances in Frontiers of Plant Science. Institute for the Advancement of Science \& Culture, New Delhi, India. 17: 187-192.

Price, J. 2010. “Green Façade Energetics.” M.S. Thesis, Environmental Science and Technology, University of Maryland, College Park. 87 pp. Available at http://hdl.handle.net/1903/11291

Putz, F. E. 1995. "Vines in treetops: consequences of mechanical dependence.” M. D. Lowman and N. M. Nadkarni (eds.). Forest Canopies. Academic Press, San Diego, CA. 311. 
Putz, F. E. and H. A. Mooney (eds.). 1991. The Biology of Vines. Cambridge University Press, Cambridge, UK.

Putz, F. E., H. A. Mooney and S. H. Bullock. 1989. Biology of vines. TREE 4:224.

Richards, P. W. 1952. The Tropical Rain Forest. University Press, Cambridge, UK.

Schumann, L.M., D.R. Tilley, 2008. Modeled effects of a roof vine canopy on indoor building temperatures in July. Sixth Annual Greening Rooftops for Sustainable Communities Conference, April - May, 2008, Baltimore, MD

Sharp, W. M. 1974. "Ecology of shrubs and vines." J. D. Gill and W. M. Healy (eds.). Shrubs and Vines for Northeastern Wildlife. Northeastern Forest Experiment Station, Forest Service, USDA, Upper Darby, PA. 2-5.

Tilley, D.R., L.M. Schumann. 2008. "Vine Inspiration: living canopy covers over roofs help mitigate urban stormwater problems." Living Architecture Monitor 10(2): 38-40 http://www.greenroofs.org/resources/LAM_Spring_2008.pdf

USDA, NRCS. 2013. The PLANTS Database (http://plants.usda.gov, 11 July 2013). National Plant Data Team, Greensboro, NC 27401-4901 USA.Van Renterghem, T., Hornikx, M., Forssen, J., Botteldooren, D., 2013. The potential of building envelope greening to achieve quietness. Building and Environment 61: 34-44 